\title{
EGÉSZSÉGPSZICHOLÓGIAI TEVÉKENYSÉGEK RELEVANCIÁJA A HONVÉD TESTALKATI PROGRAMBAN
}

\author{
DOI: $10.35926 / \mathrm{HSZ} .2020 .1 .8$
}

ÖSSZEFOGLALÓ: Az epidemiológiai kutatások egyre nagyobb szerepet tulajdonítanak az életmódnak és a viselkedésnek a krónikus nem fertőző betegségek, a túlsúly és az elhízás kialakulásában. A Magyar Honvédségben is jelentős problémaként van jelen a túlsúly és a fizikai képességek csökkenése, s e probléma megoldása érdekében indult el 2015-ben a Honvéd Testalkati Program (HTP). Tanulmányunkban a HTP részeként jelenleg is alkalmazott, illetve a jövőben bevezetni tervezett egészségpszichológiai tevékenységek bemutatásával és azok szerepével foglalkozunk az életmódváltás szemszögéből.

KULCSSZAVAK: egészségpszichológia, egészség, életmódváltás, Honvéd Testalkati Program

\section{BEVEZETÉS}

Az egészségpszichológia Joseph D. Matarazzo megfogalmazása szerint nem más, mint a pszichológia elméleti, gyakorlati ismereteinek és módszertani eszközeinek alkalmazása a következő négy területen: (1) az egészség fenntartása és fejlesztése, (2) a betegségek megelőzése, kezelése, (3) az egészség és betegség okainak és veszélyeztető tényezőinek azonosítása, valamint (4) az egészségügy és az egészségpolitika fejlesztése. ${ }^{1}$ Az epidemiológiai kutatások már közel negyven éve felhívták a figyelmet arra, hogy a krónikus nem fertőző betegségek kialakulásában, a korai halálozásban a viselkedéses és életmódbeli tényezők mintegy $50 \%$-ban játszanak szerepet. ${ }^{2}$ E tényezők - szemben a genetikai és alkati tényezőkkel - a viselkedés és az életmód megváltoztatásával kedvező irányban befolyásolhatók. Ebből következik, hogy azok a pszichológiai és viselkedéses módszerek, amelyek csökkentik a rizikótényezőket és erősítik a protektív (védő) tényezőket, sikerrel alkalmazhatók az egyén vagy a közösség egészségének fejlesztésére. Az ilyen típusú intervenciók (beavatkozások) fő célja a viselkedés változásának elősegítése.

A viselkedés változása az életmód változásával jár, hiszen az életmód nem más, mint a viselkedés olyan tartósan konzisztens mintázata, amely kulturális és evolúciós örökségen,

\footnotetext{
1 Joseph D. Matarazzo: Behavioral health's challenge to academic, scientific, and professional psychology. American Psychologist, 1982, 37:1, 1-14.

2 Healthy People - The Surgeon General's Report on Health Promotion and Disease Prevention. USDHEW, Washington, 1979. https://profiles.nlm.nih.gov/ps/access/NNBBGK.pdf (Letöltés időpontja: 2018. 03. 08.)
} 
társas kapcsolatokon, társadalmi-gazdasági helyzeten és személyiségen alapul. ${ }^{3}$ Az utóbbi években az életmódváltozást elősegítő intervenciók hatásosságát, eredményességét már nem pusztán közvetetten (a betegségteher, a krónikus nem fertőző betegségek prevalenciájának csökkenésével) igazolták, hanem megjelentek olyan kutatási eredmények is, amelyekben közvetlenül sejtszintű változásokat ( $\mathrm{pl}$. telomernövekedést ${ }^{4}$ ) is detektáltak. ${ }^{5}$

Tanulmányunkban a Honvéd Testalkati Program (HTP) során jelenleg alkalmazott és a tervezett lehetséges jövőbeli egészségpszichológiai tevékenységeket mutatjuk be. A HTP (szervezet)elméleti megközelítésben egy új honvéd egészségügyi képesség, amelynek elsődleges célja, hogy a katonai szolgálatra való egészségi, pszichikai és fizikai alkalmasságról, valamint a felülvizsgálati eljárásról szóló 10/2015 (VII. 30) HM rendeletben meghatározott testalkati követelményektől eltérő adottságú honvédek számára lehetőséget biztosítson és támogatást nyújtson a testalkati követelményeknek való megfelelés elérésére. Tanulmányunkban a „képesség” kifejezést olyan összetett, hierarchikusan felépülő szervezeti kompetencia leírására használjuk, amely a szervezetben elérhető tudásintegráció eredményeképpen jön létre. Marko Trokkeli és Markku Tuominen modellje ${ }^{6}$ a szervezeti képességek négy szintjét különbözteti meg:

1. Erőforrások és az egyéni készségek, amelyek együttesen meghatározott munkahelyi gyakorlatot hoznak létre.

2. A kapcsolódó erőforrások/egyéni képességek és a kialakuló gyakorlat során létrejönnek a tevékenység/feladat szintü képességek, egyfajta müködési rutinok mentén.

3. A működési rutinok összekapcsolódásával feladatokon, szervezeti egységeken átívelő képességek alakulnak ki, amelyek együtt funkcionális kompetenciákat teremtenek.

4. A vállalat számára meghatározó az alapvető kompetencia, amely a vállalkozás versenyképességének alapja.

A HTP hozzájárul az érintett állomány testi és lelki egészségének javításához, a hadrafoghatóság növeléséhez, ugyanis a testsúlycsökkentést elősegítő módszerek, intervenciók (pl. egészséges táplálkozást támogató és fizikai aktivitást növelö eljárások) kiemelten fontosak többek a magas vérnyomás, a szív- és érrendszeri betegségek, a magas vérzsírszint és a 2-es típusú cukorbetegség megelőzése szempontjából, amelyek az éves egészségügyi szürővizsgálatok eredményei alapján vezető megbetegedések a személyi állomány körében.

A HTP gyakorlati szempontból egy komplex életmód-tanácsadási szolgáltatás, amelybe az egészséges táplálkozást támogató és a fizikai aktivitást növelő intervenciók eredményességének érdekében egészségpszichológiai ismeretek, módszerek és tevékenységek is

\footnotetext{
Lawrence W. Green - Marshall W. Kreuter: Health promotion planning: An educational and environmental approach. Mountain View, Mayfield Pub., 1991.

4 A telomer a kromoszómát alkotó DNS-szál két végén található rövid, többszörösen ismétlődő szakasz, amely mintegy biológiai óraként megszabja, hogy egy élölény milyen hosszan élhet. Egyes, öregedéssel kapcsolatos elméletek szerint, ha a telomerek rövidülését megakadályozzuk, a sejtek élettartama elméletileg végtelenre nő.

5 Dean Ornish et al.: Increased telomerase activity and comprehensive lifestyle changes: A pilot study. Oncology, 2008, 9:11, 1048-1057.; Dean Ornish et al.: Effect of comprehensive lifestyle changes on telomerase activity and telomere length in men with biopsy-proven low-risk prostate cancer: 5-year follow-up of a descriptive pilot study. Oncology, 2013, 14:11, 1112-1120.; Luisa Soares-Miranda et al.: Physical Activity, Physical Fitness and Leukocyte Telomere Length: The Cardiovascular Health Study. Medicine and Science in Sports and Exercise, 2015, 47:12, 2525-2534.; B. H. Krishna et al.: Association of Leukocyte Telomere Length with Oxidative Stress in Yoga Practitioners. Journal of Clinical and Diagnostic Research, 2015, 9:3, 1-3.

6 Marko Torkkeli, Markku Tuominen: The contribution of technology selection to core competencies. International Journal of Production Economics, 2002, 77:3, 271-284.
} 
beépülnek. Szakirodalmi adatok támasztják alá, hogy a túlsúly és az elhízás kialakulásában fontos szerepet játszanak az evési magatartást meghatározó pszichoszociális tényezők (szociokulturális hatások, evolúciós tényezők, egyéni tapasztalat [tanulás]). ${ }^{7}$ Pszichológiai oldalról a súlyprobléma kialakulásában, illetve a testsúlycsökkentő próbálkozások kudarcában rendszerint az étkezéssel kapcsolatos maladaptív (rossz irányú) viselkedési szokások állnak, amelyek felismerését és korrekcióját kognitív viselkedésterápiás módszerekkel hatékonyan lehet kezelni. ${ }^{8}$ A túlsúly (BMI $\left.=25,0-29,9\right)$ és az enyhe, illetve mérsékelt elhízás (BMI = 30,0-39,9) kezelésének bizonyítottan hatékony módszere a kognitív viselkedésterápia. ${ }^{9} \mathrm{E}$ terápiákban a változás folyamatának facilitálására (megsegítésére) széles pszichoterápiás eszköztár áll rendelkezésünkre, amelyek közül a legfontosabbak a következők: önmonitorozás (pl. táplálkozási és aktivitási napló), ingerkontroll (pl. evést kiváltó ingerek kontrollálása), viselkedéses helyettesítés, célmeghatározás, problémamegoldás, stresszkezelés, kognitív átstrukturálás és a szociális készségek fejlesztése. ${ }^{10}$ Ugyanakkor azt is tudnunk kell, hogy a követéses vizsgálatok eredményei szerint a viselkedésterápiával ötvözött testsúlycsökkentő programban részt vevők közel 90\%-a három éven belül visszatér eredeti testsúlyához, vagyis az elhízás hosszú távú kezelése pszichológiai értelemben terápiarezisztens állapotnak tekinthető. ${ }^{11}$ A hosszú távú sikertelenség az evolúciósan kialakult adaptív evési szokásaink logikus következménye, ${ }^{12}$ de szerepet játszik benne az is, hogy az evés elsősorban nem racionális tevékenység, hanem kibogozhatatlanul bonyolult evolúciós, genetikai, biológiai, pszichológiai, kulturális és civilizációs hatások következménye. ${ }^{13}$ A hosszú távú eredményesség fenntartásához további módszerekre van szükség, s ezek közül a tudatosság növelésére irányuló ún. mindfulness módszerek kerülnek egyre inkább előtérbe.

\section{EGÉSZSÉGPSZICHOLÓGIAI TEVÉKENYSÉGEK A HONVÉD TESTALKATI PROGRAMBAN}

Az egészségpszichológiai tevékenység elméleti síkon alapvetően háromféle lehet: (1) felmérés/diagnózis, (2) konzultáció/tanácsadás vagy (3) intervenció/kezelés. Azonban az egyes tevékenységek között a gyakorlatban nem húzható éles határvonal, azok gyakran átfedést mutatnak. Tanulmányunk következő részében végighaladunk a Honvéd Testalkati Programban jelenleg alkalmazott, illetve tervezett egészségpszichológiai tevékenységeken. A felmérés/diagnózis ismertetése során részletesen bemutatjuk az általunk elkészített és bevezetett kérdőívet, röviden szemléltetve a beépített mérőeszközöket és azok relevanciáját.

\footnotetext{
7 Hornyák Beatrix: (L)étvágy - Az evés és a túlsúly pszichológiája. Honvédségi Szemle, 145. évf. 2017/5., 100-110.

8 Yasuhisa Adachi: Behavior therapy for obesity. Japan Medical Association Journal, 2005, 48:11, 539-544.; Papp Ildikó et al.: A viselkedésterápia eredményeinek vizsgálata az elhízás kezelésében egy év távlatában. Orvosi Hetilap, 155. évf. 2014/30., 1196-1202.; Thomas A. Wadden - Meghan L. Butryn: Behavioral treatment of obesity. Endocrinology and Metabolism Clinics of North America, 2003, 32:4, 981-1003.; Perczel-Forintos Dóra: Tudatosság és önreflexió - A mindfulness módszerek szerepe az elhízás kezelésében. Mentálhigiéné és Pszichoszomatika, 18. évf. 2017/2., 125-148.

9 Adachi: i. m. 539-544.; L. R. Jones - Thomas A. Wadden: State of science: Behavioral treatment of obesity. Asia Pacific Journal of Clinical Nutrition, 2006/15., 30-39.; Papp: i. m. 1196-1202.

${ }^{10}$ Perczel-Forintos Dóra - Czeglédi Edit: Falánkság, túlsúly, elhízás. Psychiatria Hungarica, 24. évf. 2009/5., 365-371.; Perczel-Forintos: i. m. 125-148.

11 Zafra Cooper et al.: Testing a new cognitive behavioural treatment for obesity: A randomized controlled trial with three-year follow-up. Behaviour Research and Therapy, 2010, 48:8, 706-713.

12 John P. Pinel et al.: Hunger, eating and ill health. American Psychologist, 2000, 55:10, 1105-1116.

13 Perczel-Forintos: i. m. 125-148.
} 
A konzultáció/tanácsadás és intervenció/kezelés vonatkozásában (összevontan: tanácsadás/ intervenció) főként azokra a tervezett jövőbeli tevékenységekre térünk ki, amelyek segítségével a program hatékonysága tovább növelhetö.

\section{Felmérés/diagnózis}

A HTP keretein belül az egészségpszichológiai felmérés egy komplex kérdőív felvételével történik, amelyet a jelentkezők elektronikus formában kapnak meg, és az első konzultációt megelőzően kell kitöltve visszaküldeniük. A kérdőív a következő fő témakörökre tagolódik:

- szociodemográfiai adatok (életkor, nem, családi állapot, iskolai végzettség);

- egészségi állapot (önminősített egészségi állapot, betegségek, gyógyszerszedés, mütétek);

- motiváció felmérése (program iránti adherencia mérése, EMI-2);

- fizikai aktivitás és viselkedésváltozás szándékának felmérése a testmozgás vonatkozásában (GPAQ, TTM-mozgás);

- táplálkozás- és viselkedésváltozás szándékának felmérése az egészséges táplálkozás vonatkozásában (TTM-táplálkozás, TFEQ-R21, étkezési magatartás);

- korábbi tapasztalatok (pl. túlsúly kezdete, korábbi testsúlycsökkentési programok tapasztalatai);

- stressz (MÁQ, PSS-10, PIK).

Az egészségi állapotra vonatkozó kérdések relevanciáját főként az adja, hogy a fennálló, orvos által diagnosztizált krónikus betegségek (pl. magasvérnyomás-betegség, cukorháztartás zavarai), a gyógyszerszedés, illetve a korábbi mütétek egy része befolyásolhatják az egyén fizikai terhelhetőségét, valamint egyéni diétás tervét, így azok regisztrálása feltétlenül szükséges. Az önminősített egészségi állapot - mint a szubjektív globális jóllét egyik fontos mutatója - a kutatási eredmények alapján jó prediktív értékkel bír az egészségi állapot objektív mutatóival kapcsolatban. ${ }^{14}$

A motiváció felmérése a testsúlycsökkentő programok résztvevőinek körében különösen fontos, hiszen a motiváció a sikeres viselkedésváltozás egyik legfontosabb prediktora (elörejelzője). A program iránti elköteleződés megítélésére korábban a szakirodalomban a compliance fogalmát használták, ami tulajdonképpen arra ad választ, hogy a kliens milyen mértékben követi a szakember elöírásait, tartja be az utasításokat, vagyis milyen mértékben viselkedik úgy, ahogyan azt tőle elvárják. Mára ez a paternalisztikus megközelítés - amely alapján a terápiás siker, eredményesség kulcsa a szakember kezében van, míg a kliens az utasítások passzív elfogadója és végrehajtója - háttérbe szorult. Napjainkban egyre inkább kezd elterjedni az adherencia kifejezés, ami betegközpontú megközelítésben a terápiához való hüséget jelenti. Mérésére egy egyszerü kérdést alkalmazunk - „Mennyire fontos Önnek a testsúlyának csökkentése?" -, a válaszokat pedig egy tízfokú skálán kell a válaszadóknak értékelniük. A kérdésre adott válasz alapján az első személyes találkozás során a motiváló és hátráltató tényezőkre következtethetünk, ha megkérdezzük, hogy a kliens miért nem adott kisebb (motiváló tényező), illetve nagyobb (hátráltató tényező) pontszámot a kérdésre.

Tekintettel arra, hogy a testsúlycsökkentő intervenciók kiemelt célja az evési szokások javítása és a fizikai aktivitás gyakoriságának növelése, fontos tisztában lennünk azzal, hogy

\footnotetext{
${ }^{14}$ Ellen L. Ilder - Yael Benyamani: Self-rated health and mortality: A review of twenty-seven community studies. Journal of Health and Social Behaviour, 1997, 38:1, 21-37.; B. Burstroem - P. Fredlund: Self-rated health: Is it a good predictor of subsequent mortality among adults in lower as well as in higher social classes? Community Health, 2001, Vol. 55, 836-840.
} 
az egyén milyen motivációs háttérrel rendelkezik a testmozgás vonatkozásában. Ennek meghatározására a testmozgás hátterében meghúzódó motivációs faktorokat vizsgáló EMI-2 (Exercise Motivations Inventory-2) ${ }^{15}$ méröeszközt használjuk. A kérdőív 51 tételt tartalmaz és 14 faktort azonosít (stresszkezelés, revitalizáció, élvezet, kihívás, társadalmi elismerés, valahová tartozás, verseny, egészségügyi nyomás, betegségek elkerülése, egészség, testsúlykontroll, megjelenés, erő és állóképesség, ruganyosság/rugalmasság). ${ }^{16}$ Az egyénre jellemző legerősebb motivációs faktorok ismerete nagy segítséget jelenthet a szakemberek számára a közös munka során.

James O. Prochaska és munkatársai ${ }^{17}$ több kognitív és viselkedésmodell integrálásával alkották meg a viselkedésváltozás transzteoretikus modelljét (TTM), amelyet alapvető elméleti keretként használunk a Honvéd Testalkati Programban, így ennek részletesebb bemutatását feltétlenül indokoltnak tartjuk.

A TTM alapján a viselkedésváltozás folyamatának hat stádiuma (szakasza) különíthető el: (1) fontolgatás elötti, (2) fontolgatás, (3) felkészülés, (4) cselekvés, (5) fenntartás és (6) befejezés - ezeket a HTP során mind a táplálkozás, mind a testmozgás vonatkozásában azonosítjuk a kérdöívben.

A fontolgatás előtti stádiumban lévők belátható időn belül nem szándékoznak változtatni viselkedésükön, mert azt nem tartják problematikusnak. Jellemző a tagadás, amelynek során a felelösséget saját hatókörükön kívül eső tényezőkre (pl. gének, család, társadalom, sors) hárítják. Önmagukra nézve ellenállnak a változásnak, a változást a külvilágra vetítve szeretnék elérni, vagyis azt szeretnék, ha a környezetük változna meg. Nem akarnak a problémáról sem hallani, sem gondolkodni, sem beszélni, így nem állnak készen a tradicionális egészségfejlesztő programokra, azok nem müködnek náluk.

A fontolgatás stádiumában lévők fel- és elismerik, hogy a viselkedésük problematikus, és elkezdenek gondolkodni a megoldáson. Rendszerint tisztában vannak azzal, hogy mit kellene tenniük, de nem állnak készen a változásra. Az elönyök és hátrányok egyensúlya ebben a szakaszban ambivalenssé válhat, ami ahhoz vezethet, hogy a „krónikus fontolgatók" tartósan elidőznek ebben a stádiumban, töprengve a problémáikon és egyre halogatva a tettek mezejére lépést. Az ebben a fázisban lévők szintén nem állnak készen a tradicionális, akcióorientált programokra, amelyek azonnali cselekvést várnak az egyéntől. A felkészülési szakaszra való áttérést a gondolkodásmód változása jelzi, amelynek során a probléma helyett a megoldás kerül előtérbe, a múlt helyett pedig a jövő.

A felkészülés stádiumában lévő személyeknek szándékukban áll a problémásnak ítélt viselkedés megváltoztatása a közeli jövőben, méghozzá az elkövetkező hónapban. Elkötelezik magukat a cselekvés mellett, azonban ez nem jelenti azt, hogy feltétlenül sikerült feloldaniuk a korábbi szakaszt jellemző ambivalenciát. Jellemző módon már megtettek kisebb-nagyobb lépéseket a cél érdekében (pl. cukor helyett édesítőszert használnak; idöközönként sétálnak egyet vacsora után), és terveket kovácsolnak a cselekvésre. Ök azok, akik készen állnak a

15 David Markland: The Exercise Motivations Inventory and Exercise Motives and Gains inventory. Exeercise Motivation Measurement, 2007. http://pages.bangor.ac.uk/ pes004/exercise_motivation/emi/emi-2.htm (Letöltés időpontja: 2016. 11. 03.)

${ }^{16}$ David Markland - David K. Ingledew: The measurement of exercise motives: Factorial validity and invariance across gender of a revised Exercise Motivations Inventory. British Journal of Health Psychology, 1997/2., 361-376.

17 James O. Prochaska et al.: In search of how people change: Applications to addictive behaviors. American Psychologist, 1992, 47:9, 1102-1114. 
változásra, akik számára megfelelő és eredményes lehet a tradicionális, cselekvésorientált egészségfejlesztő program.

A cselekvés stádiumába azok a személyek sorolhatók, akik egyértelmü, konkrét változásokat vezettek be a viselkedésükben és a környezetükben. Mindez hatalmas elköteleződést és erőfeszítést kíván az egyéntől. Hangsúlyozandó, hogy a cselekvés nem egyenlő a változással. Számos, a viselkedésváltozás előidézéséhez szükséges fejlemény (pl. az énkép vagy a gondolkodás megváltozása) a cselekvést megelőző szakaszokban történik meg.

A fenntartás stádiumában a személy aktívan dolgozik a visszaesés megelőzésén, és ezzel párhuzamosan egyre nő az önbizalma arra vonatkozóan, hogy képes fenntartani az eddig történt változtatásokat, változásokat.

A befejezés stádiumában az egyének már nem esnek kísértésbe, és az énhatékonyságuk közel 100\%-os. Bármilyen hangulati állapotban vannak is, megküzdési módként egészen biztosan nem térnek vissza a korábbi egészségkárosító szokásukhoz. A befejezés stádiuma kevéssé tünik alkalmazhatónak a testsúlymenedzselésre, hiszen az elhízottak a legritkább esetben érik el az egészségesnek tartott súlytartományt. Emellett bármennyit fogynak is, a testsúly megtartása, fizikai aktivitásuk fenntartása gyakorlatilag életre szóló munka: az evés tekintetében tartós megszorításokra, míg a fizikai aktivitás tekintetében tartós energiabefektetésre van szükség, így a viselkedésváltozás fenntartása mindvégig erőfeszítést igényel a személytől, ${ }^{18}$ már csak az életkor előrehaladtával fiziológiai okokból törvényszerüen bekövetkező súlygyarapodás miatt is. James O. Prochaska és Janice M. Prochaska ${ }^{19}$ maguk is belátják, hogy az olyan területeken, mint amilyen a fizikai aktivitás vagy a testsúlykontroll, a reális cél a fenntartás stádiumának élethosszig történö megmaradása.

A fizikai aktivitás aktuális szintjének meghatározásához a WHO globális fizikai aktivitás kérdőívét, a GPAQ-t (Global Physical Activity Questionnaire) ${ }^{20}$ használjuk, amely a heti fizikai aktivitás mértékének (MET perc/hét) becslésére szolgál. Ez összesített mérőszám formájában tájékoztat a munkavégzés, közlekedés, szabadidős tevékenység során végzett fizikai aktivitásról az eltelt hét vonatkozásában.

A táplálkozás kognitív és viselkedéses aspektusainak felmérésére egy speciálisan elhízottak részére kifejlesztett kérdőívet, a 21 tételes, háromfaktoros evési kérdőívet, a TFEQR21-et (Three-Factor Eating Questionnaire) használjuk, amelynek faktorai a következők:

- kognitív korlátozás skála: a testsúly befolyásolása érdekében történő táplálékbevitel szándékos korlátozásának mértékét méri;

- érzelmi evés skála: a negatív érzelmi, hangulati állapotban jelentkező túlevésre való hajlamot méri;

- kontrollálatlan evés skála: az éhség vagy a külső ingerek hatására bekövetkező evés feletti kontrollvesztésre való hajlamot méri.

- Az ún. érzelmi evés a negatív érzelmi-hangulati állapottal való maladaptív coping stratégia $^{21}$ (rosszul alkalmazkodó, nem célravezető megküzdési mód), amelynek

18 Thomas Baranowski et al.: Are current health behavioral change models helpful in guiding prevention of weight gain efforts? Obesity Research, 2003, 11, Suppl(S10): 23S-43S.

19 James O. Prochaska - Janice M. Prochaska: Behavior change. In: Nash, D. B. et al. (eds.): Population health: Creating a culture of wellness. Jones and Bartlett, Sudbury, 2011, 115-130.

${ }^{20}$ Global Physical Activity Questionnaire. WHO. http://www.who.int/ncds/surveillance/steps/resources/GPAQ Analysis_Guide.pdf(Letöltés időpontja: 2016. 11. 03.)

${ }^{21}$ Myles S. Faith et al.: Emotional eating and obesity: Theoretical considerations and practical recommendations. In: Sharron Dalton (ed.): Overweight and weight management: The health professional's giude to understanding and practice. Aspen Publishers, Gaithersburg, 1997, 439-465. 
azonosítása az egészséges testsúly elérése és fenntartása szempontjából kulcsfontosságú, tekintettel arra, hogy hosszú távon ez az emóciófókuszú maladaptív megküzdés súlygyarapodással jár, ${ }^{22}$ mert nassoláshoz és túlevéshez vezet. ${ }^{23}$

A stressz egy igen jelentős tényező az elhízás szempontjából, egyrészt mert obezogén tényezö ${ }^{24}$ - vagyis a testsúly szempontjából kedvezőtlen interakcióban állhat mind az energiabevitellel (megnövekedett étvágy a nagy energiasürüségü ételek iránt ${ }^{25}$ ), mind pedig az energialeadással (alacsonyabb mértékü fizikai aktivitás ${ }^{26}$ ) -, másrészt az elhízás önmagában is egy jelentős stresszforrás az egyén életében. ${ }^{27}$ A stressz mértékének becslésére az észlelt stressz kérdőív 10 tételes változatát (PSS-10) használjuk, amely a személy stresszészlelésére vonatkozó gondolatokra és érzésekre kérdez rá. ${ }^{28}$ Az egyes kérdésekre ötfokú Likert-skálán kell a válaszokat bejelölni, ahol a magasabb pontszámok a stresszhelyzetek nagyobb gyakoriságát, illetve fordított tételek esetében a sikeresebb megküzdést jelzik.

A stresszel szembeni megküzdés mérésére kétféle kérdőívet használunk: a Mentális Állóképesség Tesztet (MÁQ-teszt), amelyet speciálisan a Magyar Honvédség személyi állománya számára alakítottak ki és a pszichológiai reziliencia (rugalmas ellenállási képesség) mértékéröl tájékoztat, ${ }^{29}$ valamint a Pszichológiai Immunkompetencia Kérdőívet (PIK), amely a stresszhatások elviseléséhez és a sikeres megküzdéshez szükséges személyiségtényezőket vizsgálja. A kérdőív 80 kérdésből áll és 16 faktort vizsgál: pozitív gondolkodás, kontrollérzés, koherenciaérzés, öntisztelet, növekedésérzés, kihívás/rugalmasság, társas monitorozás/ empátia, leleményesség, énhatékonyság, társas mobilitás, szociális alkotóképesség, szinkronképesség, kitartás, impulzuskontroll, érzelmi kontroll, ingerlékenység-gátlás. ${ }^{30}$

A Honvéd Testalkati Programban jelenleg az életmódprogramok közül rutinszerüen - elsősorban a személyi feltételek hiánya miatt - a felmérést, illetve a fentiekben ismertetett mérőeszközök kiértékelését végezzük, ami a tanácsadás folyamatában nyújt segítséget az edzéselméleti és táplálkozástudományi szakembereknek.

${ }^{22}$ Paul G. Koenders - Tatjana van Strien: Emotional eating, rather than lifestyle behavior, drives weight gain in a prospective study in 1562 employees. Journal of Occupational Environment Medicine, 2011, 53:11, 1287-1293.; Joohon Sung et al.: Relationship of eating behavior to long-term weight change and body mass index: The Healthy Twin study. Eating and weight disorders, 2009, 14:2-3, e98-e105.

${ }^{23}$ Hanna Konttinen et al.: Emotional eating, depressive symptomps and self-reported food consumption. A populationbased study. Appetite, 2010, 54:3, 473-479.; E. Christaki et al.: Stress management can facilitate weight loss in Greek overweight and obese women: A pilot study. Journal of Human Nutrition and Dietetics, 2013/26. (Suppl: 1), 132-139.; Czeglédi Edit: A stresszkezelés alkalmazási lehetőségei az elhízás kezelésében. Orvosi Hetilap, 157. évf. 2016/7., 260-267.

24 Tineke de Vriendt et al.: Chronic stress and obesity in adolescents: Scientific evidence and methodological issues for epidemiological research. Nutrition, Metabolism and Cardiovascular Diseases, 2009, 19:7, 511-519.

25 Susan J. Torres - Caryl A. Nowson: Relationship between stress, eating behavior, and obesity. Nutrition, 2007, 23:1-2, 887-894.

${ }^{26}$ Matthew A. Stults-Kolchmainen - Rajita Sinha: The effects of stress on physical activity and exercise. Sports Medicine, 2014, 44:1, 81-121.

27 Czeglédi: i. m. 260-267.

28 Sheldon Cohen et al.: A global measure of perceived stress. Journal of Health and Social Behavior, 1983, 24:4, 385-396.; Stauder Adrienne - Konkoly Thege Barna: Az észlelt stressz kérdőív (PSS) magyar verziójának jellemzői. Mentálhigiéné és Pszichoszomatika, 7. évf. 2006/3., 203-216.

29 Szilágyi Zsuzsanna et al.: A mentális állóképesség-vizsgálatok bevezetésének lépései a Magyar Honvédség állományában (2006-2009). Hadtudományi Szemle, 7. évf. 2014/1., 158-178.

${ }^{30}$ Oláh Attila: Útmutató a Pszichológiai Immunkompetencia Kérdőív (PIK) használatához. ELTE, Budapest, 1999, 1-95. 


\section{TANÁCSADÁS/INTERVENCIÓ}

A HTP további fejlesztése érdekében a jövőben az egészségpszichológiai tanácsadás és intervenció vonatkozásában az itt következő tevékenységek bevezetését tervezzük: (1) motivációs interjú, (2) DUCI-WÉK és (3) evéstudatossági tréning.

A motivációs interjú (MI) technikájának kidolgozása William Miller és Stephen Rollnick nevéhez füződik. ${ }^{31}$ Egy olyan technikáról van szó, amely a tanácsadó és a kliens együttmüködésén alapul, a kliens változásra való motivációját, valamint a változáshoz szükséges erőforrásait aktiválja a kitüzött cél elérése érdekében, miközben tiszteletben tartja a kliens autonómiáját és döntési szabadságát. ${ }^{32}$ A technika célzottan a viselkedésváltozás előidézésére fókuszál, jól alkalmazható az egészségkárosító szokások megváltoztatásában, így a testsúlycsökkentő intervenciók során is. Relevanciáját mutatja, hogy az amerikai kardiológusokat, szívgyógyászokat tömörítő legnagyobb szakmai szervezet, az American Heart Association is ajánlja hatékony beavatkozásként a testsúlycsökkentő programok első hat hónapjában. ${ }^{33}$ Sarah J. Hardcastle és munkatársai randomizált kontrollált vizsgálatot végeztek az MI hoszszú távú hatékonyságának vizsgálatára 334 szív- és érrendszeri rizikófaktorral rendelkező személy körében, akiknek 99\%-a túlsúlyos vagy elhízott volt. Az MI-csoportban részt vevők a vizsgálat hat hónapjában átlagosan két, maximum öt ülésen vettek részt, ülésenként 20-30 perc időtartamban, míg a kontrollcsoport tagjai csak minimális intervencióban részesültek (tájékoztató kiadványok, életvezetési tanácsok). A követéses vizsgálat eredményei a következők szerint alakultak:

- Az MI jelentős, bár nem szignifikáns koleszterinszint-csökkenést eredményezett, míg a kontrollcsoport koleszterinszintje szignifikánsan nőtt a 18 . hónap végére.

- A vizsgálati csoport fizikai aktivitása szignifikánsan magasabb volt a 6. és a 18. hónap végén is, míg a kontrollcsoport fizikai aktivitása nem változott.

- A kontrollcsoport zsírfogyasztása szignifikánsan csökkent a 6. és a 18. hónap végén is, míg a vizsgálati csoport esetében ugyanez változatlan volt.

- A vizsgálati csoport BMI-értéke nem változott, míg a kontrollcsoport BMI-értéke szignifikánsan nőtt a 18 . hónapra. ${ }^{34}$

A motivációs interjú öt alapelvre épül: ${ }^{35}$

1. az empátia kifejezésére: elfogadás, visszatükröző figyelem, reflektív és tiszteletteljes meghallgatás;

2. a vita elkerülésére: a vita reaktanciát (vágyat arra, hogy az ellenkezőjét tegyük annak, amit tölünk elvárnak) és ellenállást válthat ki;

${ }^{31}$ William Miller - Stephen Rollnick: Motivational interviewing: Preparing people to change addictive behaviors. New York, Guilford Press, 1991, 10-50.

${ }^{32}$ Stephen Rollnick et al.: Motivational Interviewing in Health Care: Helping Patients Change Behavior. The Guilford Press, New York, 2008, 40-45.

${ }^{33}$ Sune Rubak et al.: Motivational interviewing: A systematic review and meta-analysis. British Journal of General Practice. 2005. 04. 01.; 55:513, 305-312.; Eileen Britt et al.: Motivational Interviewing in Health Settings: A Review. Patient Education and Counselling, 2004, Vol. 53, 147-155.

${ }^{34}$ Sarah J. Hardcastle et al.: Effectiveness of a motivational interviewing intervention on weight loss, physical activity and cardiovascular disease risk factors: Arandomised controlled trial with a 12 -month post-intervention follow-up. International Journal of Behavioral Nutrition of Physical Activity, 2013, 10:40, 1-16.

${ }^{35}$ Urbán Róbert: A motivációs interjú. In: Demetrivics Zsolt (szerk.): Az addiktológia alapjai, 3. kötet. ELTE, Budapest, 277-292. 
3. a diszkrepancia (ellentmondásosság) kialakítására: döntési egyensúly felállítása, szélsőségek alkalmazása, vissza- vagy előretekintés;

4. az ellenállás feldolgozására: visszatükrözés, fókuszváltás, átkeretezés, a személyes felelősség és a választás lehetőségének hangsúlyozása;

5. az önbizalom erősítésére: önmotivációs kérdések, kettős kötés alkalmazása.

A DUCI-WÉK a Williams ÉletKészségek stresszkezelő és pszichoszociális készségfejlesztő tréningnek az elhízás kezelésére adaptált változata. A DUCI szóösszetétel egy mozaikszó, amelyben a betük jelentése a következö: diet support, understanding emotions, coping enhancement, intervention. A tréning során a stresszkezelésben bizonyítottan hatékony készségek elsajátítása történik meg, amelyek közül az alapkészségek (naplójegyzet-technika, FILÉ-technika) segítenek az egyén életében jelentkező stresszforrások és érzelmek azonosításában, így különösen az emocionális éhség és a fizikai éhség megkülönböztetésében, az evést vagy túlevést kiváltó helyzetek felismerésében és tudatosításában.

A feszültséglevezetö készségek (figyelemelterelés, gondolatstop, relaxáció, átkeretezés vagy kognitív újrastrukturálás) segítenek egyrészt az evés mint maladaptív viselkedés adaptív viselkedéssel történő helyettesítésében, vagyis az érzelmi evés valamilyen örömteli tevékenységgel (masszázs, szauna, tánc, olvasás stb.) való kiváltásában; másrészt a feszültség, illetve distressz csökkentésében; és végül, de nem utolsósorban az egyénre jellemzö negatív automatikus gondolatok (kognitív torzítások) felismerésében és helyettesítésében.

A kognitív torzítások negatív érzelmekkel járnak, amelyek következtében az egyén magatartása is úgy fog alakulni, mintha igaz lenne a valójában torz, irreális gondolat, ami ismét növeli a negatív érzések gyakoriságát, ezzel egy ördögi kört eredményezve. Ilyen kognitív torzítás például a címkézés vagy a fekete-fehér (dichotóm) gondolkodás. A címkézés (,akaratgyenge vagyok, ezért nem tudok lefogyni”) és a fekete-fehér gondolkodás („megszegtem a diétámat, most már bármit megehetek, úgyis mindegy") azon túlmenően, hogy büntudatot kelt az egyénben, egyfajta felmentést is ad a számára az erőfeszítések alól.

Az akciókészségek (problémamegoldás, önérvényesítés, „nem”-et mondás) szintén nagyon hasznosak lehetnek a testsúlycsökkentő programban részt vevők számára. A problémamegoldás segíti a reális célok felállítását és az optimális megoldások kiválasztását, illetve végrehajtását, míg az asszertív, erőszakmentes kommunikáció - mint az önérvényesítés eszköze - és a „nem”-et mondás segítséget nyújthat abban, hogy megváltoztassuk a környezetünkben élők viselkedését (pl. ételek kínálása, jelenlétünkben történő nassolás), növeljük együttmüködésüket. ${ }^{36}$

A kapcsolatépitő készségek (empátia, pozitív megnyilvánulások) segítik a résztvevőket önmaguk és mások elfogadásában, a túlzott önkritika és negatív elöítéletek megszüntetésében, egy önmagukkal szembeni harmonikus, egyensúlyi állapot kialakításában.

Tekintettel arra, hogy az elhízott személyekre jellemző a külső ingerekre való nagyobb fogékonyság, így hajlamosak például stresszhelyzetben többet enni, egyre több kutatás foglalkozik a mindfulness (tudatos jelenlét) szerepével a súlycsökkentés témakörében. ${ }^{37}$ A mindfulness azt jelenti, hogy a lehető legteljesebb valónkkal vagyunk jelen az adott pillanatban, figyelmünket tudatosan arra irányítjuk, ami aktuálisan a testünkben, elménkben

\footnotetext{
${ }^{36}$ Czeglédi: i. m. 260-267.

37 Shawn N. Katterman et al.: Mindfulness meditation as an intervention for binge eating, emotional eating, and weight loss: A systematic review. Eating Behaviors, 2014, 15:2, 197-204.
} 
zajlik, kíváncsian szemlélve és elfogadva akár a negatív érzelmeket, gondolatokat is. ${ }^{38} \mathrm{Jean} \mathrm{L}$. Kristeller és Ruth Q. Wolever ${ }^{39}$ a tudatos jelenlét alapú stresszcsökkentő tréning (mindfulnessbased stress reduction - MBSR) módszerét alapul véve fejlesztették ki a tudatos jelenlét alapú evéstudatossági tréninget (mindfulness-based eating awareness training - MB-EAT) a túlevéses problémák kezelésére. A tréning öt részből áll:

1. evésmeditáció: a táplálkozással kapcsolatos érzékelések (pl. ízek, szagok, tapintás) tudatosítása;

2. testi érzések tudatosítása: éhség, sóvárgás, jóllakottság, stressz;

3. az evéshez kapcsolódó gondolatok, érzések, motivációk tudatosítása;

4. érzések, gondolatok, érzelmek ítéletmentes elfogadása;

5. tudatosság az evési szokások fokozatos megváltoztatásában.

Az evéstudatosság mérésére Celia Framson és munkatársai kifejlesztettek egy ötfaktoros, 28 tételes kérdőívet, a MEQ-t (Mindful Eating Questionnaire), ami jól használható a kutatás mellett a klinikai gyakorlatban is. ${ }^{40}$

Az evéstudatossági tréningek viszonylag új intervenciók a testsúlymenedzsmentben, így eddig még csak kevés kutatási eredmény jelent meg a hatékonyságukat illetően. A szakirodalomban egymásnak ellentmondó eredmények születtek. Katy Tapper és munkatársai nem találtak szignifikáns különbséget a testsúlycsökkenés tekintetében az intervencióban részesült csoport és a kontrollcsoport tagjai között. ${ }^{41}$ John J. Reilly és Jennifer L. Kelly huszonegy vizsgálat metaanalízise alapján megállapították, hogy a jelentudatos intervenciók 86\%-ban javulást eredményeztek az evési magatartásban, föként az érzelmi és ingervezérelt evés területén. ${ }^{42}$ Hasonló eredményre jutott Hugo J. Alberts és csapata is: eredményeik szerint egy nyolchetes mindfulness-alapú intervenciót követően az elözőekben említett evési magatartás változása mellett csökkent a résztvevők testsúlya, dichotóm gondolkodásuk és a testükkel való elégedetlenségük is. ${ }^{43}$ Az MB-EAT hatékonyságát igazolta Michail Mantzios és Janet C. Wilson vizsgálata is a testsúlycsökkenés vonatkozásában. ${ }^{44}$

\section{ÖSSZEGZÉS}

Hazánkban a testsúlymenedzsment-programok során az elhízás kialakulásában szerepet játszó pszichológiai tényezők felmérése és értékelése, illetve a kezelés során az egészségpszichológiai, viselkedésterápiás eszközök alkalmazása még nem rutinszerüen bevett gyakorlat. A legtöbb testsúlycsökkentő program sokkal inkább tekinthető egyfajta „fogyókúrának”, mintsem élet-

38 Perczel-Forintos Dóra: A kognitív terápia fénykora: A második és harmadik hullám. Magyar Pszichológiai Szemle, 2011, 66:1, 11-29.; Perczel-Forintos: i. m. 125-148.

39 Jean L. Kristeller - Ruth Q. Wolever: Mindfulness-based eating awareness training for treating binge eating disorder: The conceptual foundation. Eating Disorders, 19:1, 49-61.

${ }^{40}$ Celia Framson et al.: Development and validation of the mindful eating questionnaire. Journal of the American Dietetic Association, 2009/109., 1439-1444.

${ }^{41}$ Katy Tapper et al.: Exploratory randomized controlled trial of a mindfulness-based weight loss intervention for women. Appetite, 52:2, 396-404.

42 John J. Reilly - J. Kelly: Long-term impact of overweight and obesity in childhood and adolescence on morbidity and premature mortality in adulthood: Systematic review. International Journal of Obesity, 2010, 35:7, 891-898.

${ }^{43}$ Hugo J. Alberts et al.: Dealing with problematic eating behaviour. The effects of a mindfulness-based intervention on eating behaviour, food cravings, dichotomous thinking and body image concern. Appetite, 2012, 58:3, $847-851$

${ }^{44}$ Michail Mantzios - Janet C. Wilson: Mindfulness, Eating Behaviours, and Obesity: A Review and Reflection on Current Findings. Current Obesity Reports, 2015, 4:1, 141-146. 
módváltásnak, hiszen rendszerint csak a kalóriabevitel csökkentésére és a kalóriafelhasználás növelésére fókuszálnak, és nem veszik figyelembe azokat az egyéni pszichoszociális tényezőket, amelyek az elhízás kialakulásában szerepet játszottak. Az ilyen típusú intervenciók rövid távon eredményesek lehetnek, de hosszú távú eredményességük kétséges.

Tanulmányunk célja az volt, hogy felhívjuk a figyelmet az egészségpszichológia jelentőségére a testsúlycsökkentő programokban, és felvázoljuk azokat a Honvéd Testalkati Program során jelenleg is alkalmazott, illetve tervezett tevékenységeket, amelyek hozzájárulhatnak a program hatékonyságának növeléséhez. Ha az evéssel kapcsolatos zavarokat egy kontinuum mentén képzeljük el, amelynek egyik végén az anorexia, másik végén az obezitás áll, akkor elgondolkodtató kérdésként merül fel, hogy míg a kórosan alacsony testsúllyal járó anorexia esetében a pszichés tényezők kiemelt szerepet kapnak, addig a kórosan magas testsúllyal járó obezitás esetében ezen tényezők szerepét marginálisnak gondoljuk.

\section{FELHASZNÁLT IRODALOM}

Adachi, Yasuhisa: Behavior therapy for obesity. Japan Medical Association Journal, 2005, 48:11.

Alberts, Hugo J. - Thewissen, R. - Raes, L.: Dealing with problematic eating behaviour. The effects of a mindfulness-based intervention on eating behaviour, food cravings, dichotomous thinking and body image concern. Appetite, 2012, 58:3. DOI: 10.1016/j.appet.2012.01.009

Baranowski, Thomas - Cullen, K. W. - Nicklas, T. - Thompson, D. - Baranowski, J.: Are current health behavioral change models helpful in guiding prevention of weight gain efforts? Obesity Research, Volume 11, Suppl: S10, 2003.

Britt, Eileen - Hudson, S. M. - Blampied, N. M.: Motivational Interviewing in Health Settings: A Review. Patient Education and Counselling, Volume 53, No. 2, 2004. DOI: 10.1016/S0738-3991(03)00141-1

Burstroem, B. - Fredlund, P.: Self-rated health: is it a good predictor of subsequent mortality among adults in lower as well as in higher social classes? Community Health, Volume 55, No. 11, 2001. DOI:10.1136/jech.55.11.836

Christaki, E. - Kokkinos, A. - Costarelli, V. - Alexopolus, E. C. - Chrousos, G. P. - Darvin, C.: Stress management can facilitate weight loss in Greek overweight and obese women: a pilot study. Journal of Human Nutrition and Dietetics, Suppl: 1, 2013. DOI: 10.1111/jhn.12086

Cohen, Sheldon -Kamarck, T. - Mermelstein, R.: A global measure of Perceived Stress. Journal of Health and Social Behavior, Volume 24, No. 4, 1983.

Cooper, Zafra - Doll, Helen A. - Hawker, Deborah M. - Byrne, Susan - Bonner. Gillie - Eeley, Elizabeth - O'Connor, M. E. - Fairburn, C. G.: Testing a new cognitive behavioural treatment for obesity: A randomized controlled trial with three-year follow-up. Behaviour Research and Therapy, Volume 48, No. 8, 2010. DOI: 10.1016/j.brat.2010.03.008

Czeglédi Edit: A stresszkezelés alkalmazási lehetöségei az elhizás kezelésében. Orvosi Hetilap, 157. évf. 2016/7. DOI: 10.1556/650.2016.30362

De Vriendt, Tineke: Chronic stress and obesity in adolescents: Scientific evidence and methodological issues for epidemiological research. Nutrition, Metabolism and Cardiovascular Diseases, Volume 19, No. 7, 2009. DOI: 10.1016/j.numecd.2009.02.009

Faith, Myles S.: Emotional eating and obesity: Theoretical considerations and practical recommendations. In: Dalton, S. (ed.): Overweight and weight management: The health professional's giude to understanding and practice. Aspen Publishers, Gaithersburg, 1997.

Framson, Celia: Development and validation of the mindful eating questionnaire. Journal of the American Dietetic Association, Volume 109, No. 8, 2009. DOI: 10.1016/j.jada.2009.05.006 
Global Physical Activity Questionnaire. WHO. http://www.who.int/ncds/surveillance/steps/resources/ GPAQ_Analysis_Guide.pdf

Green, Lawrence - Kreuter, Marshall W.: Health promotion planning: an educational and environmental approach. Mountain View, Mayfield Pub., 1991.

Hardcastle, Sarah J.: Effectiveness of a motivational interviewing intervention on weight loss, physical activity and cardiovascular disease risk factors: A randomised controlled trial with a 12-month post-intervention follow-up. International Journal of Behavioral Nutrition of Physical Activity, Volume 10, No. 40, 2013. DOI: 10.1186/1479-5868-10-40.

Healthy People - The Surgeon General's Report on Health Promotion and Disease Prevention. USDHEW, Washington, 1979. https://profiles.nlm.nih.gov/ps/access/NNBBGK.pdf

Hornyák Beatrix: (L)étvágy - az evés és a túlsúly pszichológiája. Honvédségi Szemle, 145. évf. 2017/5. Ilder, Ellen L. - Benyamani, Yael: Self-rated health and mortality: A review of twenty-seven community studies. Journal of Health and Social Behaviour, Volume 38, No. 1, 1997.

Jones, L. R. - Wadden, Thomas A.: State of science: Behavioral treatment of obesity. Asia Pacific Journal of Clinical Nutrition, 15 Suppl, 2006.

Katterman, Shawn N.: Mindfulness meditation as an intervention for binge eating, emotional eating, and weight loss: A systematic review. Eating Behaviors, Volume 15, No. 2, 2014. DOI: 10.1016/ j.eatbeh.2014.01.005

Koenders, Paul G. - Strien, van Tatjana: Emotional eating, rather than lifestyle behavior, drives weight gain in a prospective study in 1562 employees. Journal of Occupational Environment Medicine, Volume 53, No. 11, 2011. DOI: 10.1097/JOM.0b013e31823078a2

Konttinen, Hanna: Emotional eating, depressive symptomps and self-reported food consumption. A population-based study. Appetite, Volume 54, No. 3, 2010. Doi: 10.1016/j.appet.2010.01.014

Krishna, B. H.: Association of Leukocyte Telomere Length with Oxidative Stress in Yoga Practitioners. Journal of Clinical and Diagnostic Research, Volume 9, No. 3, 2015. DOI: 10.7860/ JCDR/2015/13076.5729

Kristeller, Jean L. - Wolever, Ruth Q.: Mindfulness-based eating awareness training for treating binge eating disorder: the conceptual foundation. Eating Disorders, Volume 19, No. 1, 2011. DOI: 10.1080/10640266.2011.533605

Mantzios, Michail - Wilson, Janet C.: Mindfulness, Eating Behaviours, and Obesity: A Review and Reflection on Current Findings. Current Obesity Reports, Volume 4, No. 1, 2015. DOI: 10.1007/ s13679-014-0131-x

Markland, David - Ingledew, David K.: The measurement of exercise motives: Factorial validity and invariance across gender of a revised Exercise Motivations Inventory. British Journal of Health Psychology, Volume 2, 1997.

Markland, David: The Exercise Motivations Inventory and Exercise Motives and Gains inventory. Exercise Motivation Measurement. http://pages.bangor.ac.uk/ pes004/exercise_motivation/emi/ emi-2.htm

Matarazzo, Joseph D.: Behavioral health's challenge to academic, scientific, and professional psychology. American Psychologist, Volume 37, No. 1, 1982.

Miller, William - Rollnick, Stephen: Motivational interviewing: preparing people to change addictive behaviors. New York, Guilford Press, 1991.

Oláh Attila: Útmutató a Pszichológiai Immunkompetencia Kérdőiv (PIK) használatához. ELTE, Budapest, 1999.

Ornish, Dean: Effect of comprehensive lifestyle changes on telomerase activity and telomere length in men with biopsy-proven low-risk prostate cancer: 5-year follow-up of a descriptive pilot study. Oncology, Volume 14, No. 11,2013. DOI: 10.1016/S1470-2045(13)70366-8 
Ornish, Dean: Increased telomerase activity and comprehensive lifestyle changes: a pilot study. Oncology, Volume 9, No. 11, 2008. DOI: 10.1016/S1470-2045(08)70234-1

Papp Ildikó et al.: A viselkedésterápia eredményeinek vizsgálata az elhízás kezelésében egy év távlatában. Orvosi Hetilap, 155. évf. 2014/30.

Perczel-Forintos Dóra: A kognitiv terápia fénykora - A második és harmadik hullám. Magyar Pszichológiai Szemle, 66. évf. 2011/1.

Perczel-Forintos Dóra: Tudatosság és önreflexió - A mindfulness módszerek szerepe az elhízás kezelésében. Mentálhigiéné és Pszichoszomatika, 18. évf. 2017/2. DOI: 10.1556/0406.18.2017.006

Perczel-Forintos Dóra - Czeglédi Edit: Falánkság, túlsúly, elhízás. Psychiatria Hungarica, 24. évf. 2009/5.

Pinel, John P.: Hunger, eating and ill health. American Psychologist, Volume 55, No. 10, 2000.

Prochaska, James O. - Prochaska, Janice M.: Behavior change. In: Nash, D.B. (ed.): Population health: Creating a culture of wellness. Jones and Bartlett, Sudbury, 2011.

Prochaska, James O.: In search of how people change: Applications to addictive behaviors. American Psychologist, Volume 47, No. 9, 1992.

Reilly, J. J. - Kelly, J.: Long-term impact of overweight and obesity in childhood and adolescence on morbidity and premature mortality in adulthood: systematic review. International Journal of Obesity, Volume 35, No. 7, 2010. DOI: 10.1038/ijo.2010.222

Rollnick, Stephen et al:: Motivational Interviewing in Health Care: Helping Patients Change Behavior. The Guilford Press, New York, 2008.

Rubak Sune: Motivational interviewing: a systematic review and meta-analysis. British Journal of General Practice, Volume 55, No. 513, 2005.

Soares-Miranda, Luisa: Physical Activity, Physical Fitness and Leukocyte Telomere Length: the Cardiovascular Health Study. Medicine and Science in Sports and Exercise, Volume 47, No. 12, 2015. DOI: 10.1249/MSS.0000000000000720

Stauder Adrienne - Konkoly-Thege Barna: Az észlelt stressz kérdőív (PSS) magyar verziójának jellemzői. Mentálhigiéné és Pszichoszomatika, 7. évf. 2006/3.

Stults-Kolchmainen, Matthew A. - Sinha, Rajita: The effects of stress on physical activity and exercise. Sports Medicine, Volume 44, No. 1, 2014. DOI: 10.1007/s40279-013-0090-5

Sung, Joohon: Relationship of eating behavior to long-term weight change and body mass index: the Healthy Twin study. Eating and Weight Disorders, Volume 14, No. 2-3, 2009.

Szilágyi Zsuzsanna: A mentális állóképesség vizsgálatok bevezetésének lépései a Magyar Honvédség állományában (2006-2009). Hadtudományi Szemle, 7. évf. 2014/1

Tapper, Katy: Exploratory randomized controlled trial of a mindfulness-based weight loss intervention for women. Appetite, Volume 52, No. 2, 2009. DOI: 10.1016/j.appet.2008.11.012

Torkkeli, Marko - Tuominen, Markku: The contribution of technology selection to core competencies. International Journal of Production Economics, 2002, 77:3.

Torres, Susan J. - Nowson, Caryl A.: Relationship between stress, eating behavior, and obesity. Nutrition, Volume 23, No. 1-2, 2007. DOi: 10.1016/j.nut.2007.08.008

Urbán Róbert: A motivációs interjú. In: Demetrovics Zsolt (szerk.): Az addiktológiai alapjai, 3. ELTE - Eötvös Kiadó, Budapest, 2009.

Wadden, Thomas A. - Butryn, Meghan L.: Behavioral treatment of obesity. Endocrinology and Metabolism Clinics of North America, Volume 32, No. 4, 2003. DOI: 10.1016/S0889-8529(03)00072-0 